\title{
De ontslagbescherming van onderwijzend personeel
}

\author{
Mr.dr. Elmira van Vliet*
}

\section{Inleiding}

Gedurende lange tijd heeft onderwijzend personeel in het bijzonder onderwijs een afwijkende ontslagbescherming gekend vergeleken met werknemers in het bedrijfsleven. Tot de invoering van de Wet werk en zekerheid (hierna: Wwz) in 2015 was personeel in het bijzonder onderwijs uitgezonderd van de toepasselijkheid van het Buitengewoon Besluit Arbeidsverhoudingen 1945 (BBA), als gevolg waarvan geen preventieve ontslagtoets van toepassing was. Werknemers in het bijzonder onderwijs konden tegen het besluit tot ontslag wel beroep instellen bij een commissie van beroep, waar deskundigen op het terrein van het onderwijs(arbeids)recht oordeelden over het ontslag. ${ }^{1}$ Een commissie van beroep kon het beroep gegrond, ongegrond of niet-ontvankelijk verklaren. Er was echter discussie over de juridische status van een uitspraak van de commissie van beroep en de vraag of de werkgever en werknemer hieraan waren gebonden. De Hoge Raad heeft in 1996 geoordeeld dat een werknemer niet was gebonden aan een uitspraak van een commissie van beroep, tenzij een werkgever en werknemer dat ondubbelzinnig waren overeengekomen. ${ }^{2}$

Sinds de invoering van de Wwz is het 'reguliere' ontslagrecht voor werknemers in het bijzonder onderwijs van toepassing geworden. Dat neemt niet weg dat er nog wel bijzonderheden kleven aan ontslag van een onderwijswerknemer, bijvoorbeeld als het gaat om ontslag dat verband houdt met de grondslag van de school. Verder is er sinds de invoering van de Wwz de nodige rechtspraak verschenen over onderwijswerknemers en is er veel te doen om de ketenregeling in het onderwijs. Deze ontwikkelingen zullen in dit artikel worden besproken. Dit is te meer van belang, omdat op 1 januari 2020 de Wet normalisering rechtspositie ambtenaren (hierna: Wnra) in werking zal treden. Onderwijspersoneel in het openbaar onderwijs zal vanaf die datum ook werkzaam zijn op basis van een arbeidsovereenkomst, waardoor het arbeidsrecht zoals dat nu al geldt voor personeel in het

Elmira van Vliet is universitair docent bij Erasmus School of Law.

1. Zie over deze commissies van beroep: E. van Vliet, Commissies van beroep in het bijzonder onderwijs (diss. EUR), Den Haag: Boom juridisch 2016

2. HR 31 mei 1996, NJ 1996, 693 m.nt. P.A. Stein (Amghane). bijzonder onderwijs (met uitzondering van de onderwijsidentiteitsontslagcommissie, waarover hierna meer) in de gehele onderwijssector van toepassing zal zijn. ${ }^{3}$

In dit artikel zullen allereerst het onderscheid tussen het openbaar en bijzonder onderwijs en de rechtspositionele consequenties hiervan worden besproken ( $(2)$. Daarbij zal ook de Wnra aan de orde worden gesteld ( $\$ 3$ ). Vervolgens zullen de identiteitsontslagcommissie, caoontslagcommissie en de ketenregeling in het bijzonder onderwijs worden besproken $(\S 4,5$ en 6$)$. Daarna zal nader worden ingegaan op de rechtsbescherming bij ontslag ( $(7)$ en zal recente jurisprudentie van de Hoge Raad met betrekking tot de onderwijswerknemer aan de orde komen ( $(8)$, waarna deze bijdrage wordt afgesloten met een conclusie $(\S 9)$.

\section{Openbaar en bijzonder onderwijs: gevolgen voor rechtspositie personeel}

Voor wat betreft de ontslagbescherming van onderwijzend personeel is allereerst van belang vast te stellen of iemand werkzaam is in het openbaar onderwijs, dan wel het bijzonder onderwijs. ${ }^{4}$ In Nederland kennen we namelijk een zogenoemd duaal onderwijsbestel. Openbaar onderwijs is levensbeschouwelijk neutraal, gaat uit van en is de verantwoordelijkheid van de overheid (art. 23 lid 4 Grondwet). De meest voorkomende bestuursvorm in het openbaar onderwijs is de stichting openbaar onderwijs. Het personeel is dan werkzaam in openbare dienst en is werkzaam als ambtenaar. ${ }^{5}$ Bijzonder onderwijs daarentegen wordt niet van overheidswege gegeven en hoeft niet levensbeschouwelijk neutraal te zijn. Een bijzondere school wordt in stand gehouden door een vereniging of een stichting. Perso-

3. Zie over de gevolgen voor personeel in het openbaar onderwijs: L.C.J. Sprengers e.a. Op weg naar één arbeidsrecht voor de gehele onderwijssector. Gevolgen van de Wet normalisering rechtspositie ambtenaren (Wnra) voor ambtenaren in het openbaar primair en voortgezet onderwijs en aandachtspunten voor cao-partijen, Utrecht: Expertisecentrum Onderwijsgeschillen 2019.

4. Zie over de verschillende rechtsposities: F.H.J.G. Brekelmans en E. van Vliet, 'De leraar', in: G.W. van der Voet (red.), Arbeidsrechtelijke themata - Bijzondere arbeidsverhoudingen, Den Haag: Boom juridisch 2017, p. 101-142.

5. P.W.A. Huisman e.a., Basisboek onderwijsrecht, Den Haag: Sdu Uitgevers 2017, p. 83. 
neel dat werkt in het bijzonder onderwijs is werkzaam op basis van een arbeidsovereenkomst. Titel 10 van Boek $7 \mathrm{BW}$ is van toepassing. Verder is het mogelijk dat openbare en bijzondere scholen onder een gemeenschappelijk bestuur vallen. Dit wordt het samenwerkingsbestuur genoemd (art. 17 Wet op het primair onderwijs (hierna: WPO) en art. 53c Wet op het voortgezet onderwijs (hierna: WVO)). De wet bepaalt dat het personeel dat in dienst is van een samenwerkingsbestuur werkzaam is op basis van een arbeidsovereenkomst, ook als iemand feitelijk op een openbare school werkzaam is (art. 17 lid 4 WPO en art. 53c lid 4 WVO). Tot slot is het na een fusie ook mogelijk dat op een school zowel openbaar als bijzonder onderwijs wordt gegeven. Ook in die situatie is het personeel werkzaam op basis van een arbeidsovereenkomst (art. 17d lid 4 WPO en art. 53d lid 4 WVO). Samenvattend is op personeel in het openbaar onderwijs het ambtenarenrecht van toepassing. Voor personeel dat werkzaam is in het bijzonder onderwijs, voor een samenwerkingsbestuur of op een samenwerkingsschool is het arbeidsrecht van toepassing. Alleen in het primair onderwijs, het voortgezet onderwijs en het wetenschappelijk onderwijs bestaat de tweedeling tussen openbaar en bijzonder onderwijs en daarmee de toepasselijkheid van het ambtenarenrecht en het arbeidsrecht op het personeel. In het middelbaar beroepsonderwijs en in het hoger onderwijs zijn er alleen bijzonder onderwijsinstellingen, zodat op het personeel in dienst van deze instellingen het arbeidsrecht van toepassing is. ${ }^{6}$

Naast het wettelijk kader zijn de cao's in de verschillende onderwijssectoren voor de rechtspositie van het personeel van groot belang. $\mathrm{Nu}$ een cao niet rechtstreeks van toepassing is op de ambtenaar in het openbaar onderwijs, wordt deze omgezet in een algemeen verbindend voorschrift. Hiermee wordt bewerkstelligd dat de arbeidsvoorwaarden zoals opgenomen in de cao ook voor personeel in het openbaar onderwijs van toepassing zijn. In de onderwijs-cao's (de CAO Primair Onderwijs 2018-2019, de CAO Voortgezet Onderwijs 2018-2019 en de CAO Nederlandse Universiteiten 2017-2019) zijn bepalingen opgenomen die zowel op personeel in het openbaar als in het bijzonder onderwijs van toepassing zijn. De cao's bevatten echter ook hoofdstukken die gericht zijn op het personeel in het openbaar en bijzonder onderwijs afzonderlijk. Kortom, voor wat betreft de rechtspositie van het personeel is het altijd van belang te bepalen of iemand in het openbaar of bijzonder onderwijs werkzaam is. Dit gaat in de toekomst echter voor een belangrijk deel veranderen.

\section{Wet normalisering rechtspositie ambtenaren in het onderwijs}

Op 8 november 2016 is het initiatiefwetsvoorstel 'Wet normalisering rechtspositie ambtenaren' (hierna: Wnra) door de Eerste Kamer aangenomen. Vervolgens is op 17 april 2019 de Aanpassingswet Wnra door de Eerste Kamer aangenomen. ${ }^{7}$ Kort samengevat is het doel van de Wnra de rechtspositie van ambtenaren en werknemers in het private bedrijfsleven gelijk te trekken. ${ }^{8}$ Als gevolg van de Wnra zal de publiekrechtelijke eenzijdige aanstelling van de ambtenaar verdwijnen en op 1 januari 2020, de beoogde inwerkingtredingsdatum, van rechtswege worden omgezet in een privaatrechtelijke arbeidsovereenkomst. Het civiele arbeidsrecht zal dan van toepassing worden op ambtenaren. De benaming 'ambtenaar' en de Ambtenarenwet zullen nog wel blijven bestaan. Zo bepaalt artikel 1 lid 1 van de nieuwe Ambtenarenwet (hierna: AW 2017) dat 'een ambtenaar in de zin van deze wet degene is die krachtens een arbeidsovereenkomst met een overheidswerkgever werkzaam is'. Bepaalde sectoren zijn overigens uitgezonderd van de Wnra, zoals de politie en de rechterlijke macht. De Wnra heeft belangrijke consequenties voor de onderwijssector. ${ }^{9}$ Sterker nog: specifiek voor de onderwijssector is een apart wetsvoorstel ingediend (hierna: Wnra Onderwijs), om ervoor te zorgen dat voor het gehele openbaar onderwijs, en daarmee voor de gehele onderwijssector (want voor het bijzonder onderwijs is dat nu al het geval), het arbeidsrecht van toepassing zal gaan worden. ${ }^{10}$

In de Wnra Onderwijs is wetgeving opgenomen als gevolg waarvan de eenzijdige publiekrechtelijke aanstelling wordt vervangen door een tweezijdige privaatrechtelijke arbeidsovereenkomst en de eenzijdige rechtspositiebepalingen tot het verleden behoren. Daarnaast wordt met de Wnra Onderwijs bewerkstelligd dat het gehele openbaar onderwijs wordt uitgesloten van de

7. Stb. 2019,173

8. Zie over de Wnra bijvoorbeeld: N. Hummel, 'Het ambtenarenrecht is dood, lang leve het ambtenarenrecht', ArbeidsRecht 2017/20 en M.B. de Witte-van den Haak, 'Wet normalisering rechtspositie ambtenaren: dogmatisch grotere verschillen dan in de praktische uitwerking', TAP 2017/164, nr.4, p. 12-13 en B. Barentsen, 'Normalisering ambtelijke rechtspositie', NJB 2017/420.

9. Zie uitgebreid: F.H.J.G. Brekelmans en E. van Vliet, 'Wet normalisering rechtspositie ambtenaren en het openbaar onderwijs', School en Wet, juni 2018, p. 10-15 en E. van Vliet, 'Wnra in het onderwijs. Rechtspositie onderwijspersoneel openbaar onderwijs wordt normaal, maar blijft een beetje bijzonder', in: B. Barentsen, N. Hummel en S.F.H. Jellinghaus (red), Van ambtenaar naar ambtenaar. De Wet normalisering rechtspositie ambtenaren, Weert: Celsus uitgeverij 2018, p. 187-195.

10. Wijziging van enige wetten in verband met de normalisering van de rechtspositie van ambtenaren in het onderwijs, Kamerstukken II 2018/19, 35089, 2. 
AW 2017. ${ }^{11}$ Wat is de gedachte hierachter? Voor het openbaar onderwijs dat door de gemeente is ondergebracht bij een private stichting (dit komt in het openbaar onderwijs het meest voor), brengt de Wnra sowieso met zich dat het arbeidsrecht van toepassing wordt en de AW 2017 niet van toepassing is. Aan de definitie van het begrip overheidswerkgever, zoals opgenomen in artikel 2 AW 2017, wordt namelijk niet voldaan. Aanvankelijk zou dat voor openbaar onderwijs waarbij de gemeente het bevoegd gezag is en voor de openbare universiteiten, de openbare onderzoeksinstellingen en de openbare universitaire medische centra anders zijn. $Z$ ij zouden namelijk wel vallen onder de definitie 'overheidswerkgever' als bedoeld in artikel 2 AW 2017. ${ }^{12}$ Dit zou tot gevolg hebben dat er voor wat betreft de rechtspositie van personeel nog steeds een onderscheid zou blijven bestaan tussen het openbaar en het bijzonder onderwijs, maar ook dat er binnen het openbaar onderwijs een onderscheid zou ontstaan (namelijk tussen het wel en niet van toepassing zijn van de AW 2017). De regering heeft dat vanwege de eenheid van rechtspositie, het voorkomen van administratieve lasten en vermindering van regelgeving onwenselijk gevonden. Daarbij komt dat de AW 2017 is toegespitst op werken in het openbaar bestuur en volgens de regering minder goed past bij de praktijk van het onderwijs. Binnen de onderwijssectoren zijn al op de sectoren toegesneden afspraken gemaakt over zaken als nevenwerkzaamheden, integriteit en het melden van misstanden, waardoor de meer algemene bepalingen hierover in de AW 2017 voor de onderwijssector minder passend zijn. ${ }^{13} \mathrm{Om}$ deze redenen wordt in artikel 2 AW 2017 geregeld dat gemeenten géén overheidswerkgever zijn indien en voor zover zij scholen in stand houden waarvan het college van $B \& W$ het bevoegd gezag is, respectievelijk dat openbare rechtspersonen in de zin van de WPO, de Wet op de expertisecentra (hierna: WEC) en de WVO ook geen overheidswerkgever zijn. Het gevolg is dat de AW 2017 binnen de gehele onderwijssector niet van toepassing is en al het personeel in de onderwijssector werkzaam zal zijn op basis van een privaatrechtelijke arbeidsovereenkomst.

11. Zie over de Wnra-onderwijs: L.C.J. Sprengers e.a. Op weg naar één arbeidsrecht voor de gehele onderwijssector. Gevolgen van de Wet normalisering rechtspositie ambtenaren (Wnra) voor ambtenaren in het openbaar primair en voortgezet onderwijs en aandachtspunten voor cao-partijen, Utrecht: Expertisecentrum Onderwijsgeschillen 2019, p. 11-14.

12. Zie over de gevolgen van de Wnra voor universiteiten: L.H. Janssen, ‘De gevolgen van de Wet normalisering rechtspositie ambtenaren voor het personeel van openbare universiteiten', NTOR, 3 oktober 2017, p. 171-190.

13. Kamerstukken I/ 2018/19, 35089, 3, p. 2-3.

\section{Bijzondere ontslagregels: onderwijsidentiteitsontslag- commissie}

Hoewel sinds de invoering van de $\mathrm{Wwz}$ het reguliere ontslagrecht van toepassing is op de werknemer in het bijzonder onderwijs, is er wel exclusief voor het bijzonder onderwijs een zogenoemde 'onderwijsidentiteitsontslagcommissie' (afgekort: OIOC) in het leven geroepen. ${ }^{14}$ De wettelijke basis voor deze commissie is te vinden in artikel 7:671 lid 1 aanhef en onder h BW. In dit wetsartikel is geregeld dat de werkgever de arbeidsovereenkomst niet rechtsgeldig kan opzeggen zonder de schriftelijke instemming van de werknemer, tenzij de opzegging een werknemer in het bijzonder onderwijs betreft en de reden voor de opzegging is gelegen in handelen of nalaten van de werknemer dat onverenigbaar is met de uit de godsdienstige of levensbeschouwelijke grondslag voortvloeiende identiteit van de desbetreffende school of instelling, mits voor de opzegging toestemming is verleend door een van de werkgever onafhankelijke en onpartijdige commissie. De regels betreffende de cao-ontslagcommissie (art. 7:671a lid 2 onder a tot en met d BW) zijn van overeenkomstige toepassing verklaard. De Vereniging Gereformeerd Schoolonderwijs (VGS) heeft een OIOC ingesteld. Hoewel een identiteitsontslag in de praktijk zelden aan de orde is, kwam eind 2018 in de media een identiteitsontslag van een docent in het reformatorisch onderwijs aan de orde. ${ }^{15}$ Het gaat in deze zaak om een ex-gokverslaafde vmbo-docent aan een reformatorische school die een theaterstuk maakte (en daar ook in wilde gaan spelen) over zijn gokverslaving. De school vond theater niet passen bij de reformatorische grondslag van de school en wilde de docent om die reden ontslaan. De school heeft de OIOC verzocht toestemming voor opzegging te verlenen. De OIOC was van oordeel dat de docent handelde in strijd met de identiteit van de school en verleende toestemming voor opzegging van de arbeidsovereenkomst. ${ }^{16}$ Deze zaak heeft geleid tot Kamervragen, waarbij de minister van Onderwijs, Cultuur en Wetenschap werd gevraagd wat hij van het ontslag vond. Minister Slob antwoordde dat de onafhankelijkheid van de OIOC is gewaarborgd in het reglement van de commissie en dat de OIOC in het arbeidsrecht wettelijk is geregeld. De minister weigerde in de beoordeling van het ontslag te treden: hij gaf an dat de OIOC het voorgenomen ontslag heeft goedgekeurd en dat hij daar verder geen rol in heeft. ${ }^{17}$

De werknemer kan bij een identiteitsontslag na het oordeel van de OIOC de kantonrechter op grond van artikel 7:682 lid 2 BW verzoeken de arbeidsovereenkomst te

14. Kamerstukken // 2013/14, 33818, 52

15. 'Docent reformatorische school mag worden ontslagen om theaterstuk', www.nos.nl, 10 november 2018.

16. Voor zover ik heb kunnen nagaan, is de uitspraak van de OIOC niet openbaar gepubliceerd.

17. Brief van 2 november 2018, ref. $2018 Z 18287$ 
herstellen indien de opzegging in strijd is met artikel 7:669 BW of hij kan de kantonrechter verzoeken hem een billijke vergoeding toe te kennen vanwege ernstig verwijtbaar handelen of nalaten van de werkgever. Het identiteitsontslag zoals opgenomen in artikel 7:671 lid 1 onder $\mathrm{h} \mathrm{BW}$ is eigenlijk een aparte ontslaggrond naast de gronden van artikel 7:669 lid $3 \mathrm{BW}$ en leidt tot juridische vragen. Hoe ver gaat bij een identiteitsontslag de toetsing door de rechter op grond van artikel 7:682 lid 2 $\mathrm{BW}$ ? Is artikel 7:669 BW volledig onverkort van toepassing en is er in geval van een identiteitsontslag wel altijd sprake van een redelijke grond als bedoeld in artikel 7:669 lid 3 BW? Op deze vragen geeft de parlementaire geschiedenis van de Wwz geen sluitend antwoord. Naar mijn idee zal als (gelet op de tekst van art. 7:682 lid 2 BW) wordt aangenomen dat artikel 7:669 BW onverkort van toepassing is, in geval van een identiteitsontslag niet altijd ook sprake zijn van een van de ontslaggronden zoals opgenomen in artikel 7:669 lid 3 BW. Mogelijk zal een identiteitsontslag wel onder de h-grond kunnen worden geschaard, hoewel de wetgever deze ontslaggrond heeft gereserveerd voor uitzonderlijke situaties. ${ }^{18}$

\section{Cao-ontslagcommissie}

In artikel 7:671a lid $2 \mathrm{BW}$ is de cao-ontslagcommissie wettelijk geregeld, die in geval van opzegging wegens bedrijfseconomische redenen (art. 7:669 lid 3 onder a BW) in plaats van het UWV kan oordelen over het al dan niet verlenen van toestemming voor ontslag en die van het afspiegelingsbeginsel afwijkende selectiecriteria mag toepassen (art. 7:669 lid 6 BW). ${ }^{19}$ In het bijzonder onderwijs is er tot op heden alleen in het hoger beroepsonderwijs voor gekozen een cao-ontslagcommissie in te stellen. ${ }^{20}$ In artikel S-1 van de CAO HBO 2018-2020 is geregeld dat de ontslagcommissie in haar oordeel betrekt de ontslagcriteria zoals vastgesteld in het voor het desbetreffende ontslag geldende sociaal plan, dat als cao is aangemeld bij de Inspectie SZW. Indien geen ontslagcriteria zijn vastgesteld, gelden de ontslagcriteria van par. 4 van de Ontslagregeling (afspiegelingsbeginsel). Bedrijfseconomisch ontslag komt in het hoger beroepsonderwijs niet vaak voor. Tot op heden heeft de caoontslagcommissie in het hoger beroepsonderwijs slechts één zaak behandeld, waarbij de Ontslagregeling het toetsingskader was. Toestemming voor opzegging wegens bedrijfseconomische redenen werd in deze zaak geweigerd, omdat de werkgever onvoldoende had aangetoond dat er geen herplaatsingsmogelijkheden waren. ${ }^{21}$

18. Zie over deze complicaties: E. van Vliet, Commissies van beroep in het bijzonder onderwijs (diss. EUR), Den Haag: Boom juridisch 2016, p. 261-264.

19. Zie over de cao-ontslagcommissie: A.R. Houweling (red.) e.a., Loonstra \& Zondag. Arbeidsrechtelijke Themata II, Den Haag: Boom juridisch 2018, p. 137-153

20. Zie ook: E. van Vliet, 'Ontslag van werknemers in het bijzonder onderwijs en commissies van beroep anno 2017', ArbeidsRecht 2017/25.

21. Sectorale ontslagcommissie hbo 3 april 2018, 108064, www.onderwijsgeschillen.nl.
$\mathrm{Na}$ inwerkingtreding van de Wnra kan een cao-ontslagcommissie ook voor het openbaar onderwijs ingesteld worden, wat met name vanwege het overgangsrecht bij reorganisaties een interessante optie kan zijn. ${ }^{22}$

\section{Ketenregeling}

Met het wetsvoorstel 'Wet arbeidsmarkt in balans' (hierna: WAB), dat op 28 mei 2019 door de Eerste Kamer is aangenomen, wordt de ketenregeling (art. 7:668a BW) van 24 maanden verruimd naar 36 maanden, zodat de maximale duur van de keten weer gelijk is als voor de invoering van de Wwz en drie aaneensluitende contracten voor bepaalde tijd kunnen worden overeengekomen in een periode van drie jaar. In het primair onderwijs wordt de ketenregeling als knelpunt ervaren, omdat in geval van vervanging bij ziekte vaak noodgedwongen met kortdurende tijdelijke contracten wordt gewerkt (soms zelfs een contract van slechts enkele dagen) en vanwege het grote aantal kortdurende contracten al snel een contract voor onbepaalde tijd zal ontstaan. De bedrijfsvoering makt het vaak niet mogelijk vaste invallers of een parttime leerkracht voor de klas te zetten. Schoolbesturen hebben bij ziekte moeite om invallers te vinden, omdat invallers maar korte tijd voor een schoolbestuur kunnen werken (namelijk tot zij het maximum van de ketenbepaling hebben bereikt). Bij ministeriële regeling is derhalve voor het primair onderwijs een uitzondering op de ketenregeling gemaakt voor zover de arbeidsovereenkomst is aangegaan in verband met vervanging wegens ziekte van een werknemer die een onderwijsgevende of onderwijsondersteunende functie met lesgebonden of behandeltaken bekleedt. ${ }^{23}$ In artikel 3.1 lid 5 CAO PO 2018-2019 is deze uitzondering opgenomen, waardoor in geval van vervanging bij ziekte gedurende een periode van drie jaar een onbeperkt aantal tijdelijke contracten kan worden overeengekomen. In de WAB wordt een (verdergaande, volledige) uitzondering op de ketenregeling voor het bijzonder onderwijs in de wet opgenomen. Het nieuwe artikel 7:668a lid 15 BW bepaalt het volgende:

'Dit artikel is niet van toepassing op een arbeidsovereenkomst met een werknemer op een school als bedoeld in artikel 1 van de Wet op het primair onderwijs of artikel 1 van de Wet op expertisecentra, indien de arbeidsovereenkomst is aangegaan in verband met vervanging wegens ziekte van een werknemer die een onderwijsgevende of onderwijsondersteunende functie met lesgebonden of behandeltaken bekleedt.'

22. Zie hierover: L.C.J. Sprengers e.a. Op weg naar één arbeidsrecht voor de gehele onderwijssector. Gevolgen van de Wet normalisering rechtspositie ambtenaren (Wnra) voor ambtenaren in het openbaar primair en voortgezet onderwijs en aandachtspunten voor cao-partijen, Utrecht: Expertisecentrum Onderwijsgeschillen 2019, p. 45-46.

23. Art. 1 onder $g$ Regeling ketenbepaling bijzondere functies en hogere vergoeding kantonrechter. 
Uit de memorie van toelichting volgt dat volgens de regering de uitzondering op de ketenbepaling in het basisonderwijs (en speciaal basisonderwijs) gerechtvaardigd is. Het voorziet - zoals blijkt uit diverse onderzoeken en evaluaties - in een behoefte die door sociale partners wordt ondersteund, waarbij het onwenselijk wordt gevonden de uitzondering afhankelijk te maken van cao-onderhandelingen. Invalkrachten in het primair onderwijs zijn een bijzondere groep en de wettelijke ketenregeling belemmert besturen om voldoende tijdelijke invalkrachten te vinden. Lesuitval dreigt, waardoor de wettelijk voorgeschreven minimale onderwijstijd in gevaar komt met mogelijke consequenties voor schoolbesturen (sancties met betrekking tot bekostiging) van dien. Daarbij komt ook dat lesuitval als maatschappelijk onwenselijk wordt gezien. ${ }^{24}$

Op de wettelijke volledige uitsluiting van de ketenregeling in geval van vervanging bij ziekte in het primair onderwijs is, naar mijn idee terecht, de nodige kritiek gekomen. Uit het advies van de Afdeling Advisering van de Raad van State volgt dat in het primair onderwijs de werknemersbescherming beperkter is dan in andere sectoren. Uit de memorie van toelichting blijkt volgens de Afdeling onvoldoende waarom soortgelijke problematiek zich in andere sectoren niet voor kan doen en waarom andere instrumenten zoals de oproepovereenkomst de problematiek niet zouden kunnen verlichten. Kortom, een dragende motivering voor de wettelijke uitzondering voor het primair onderwijs ontbreekt, volgens de Afdeling. ${ }^{25}$ Kamerlid Gijs van Dijk heeft een amendement ingediend en zich op het standpunt gesteld dat toekomstige leerkrachten op zoek zijn naar zekerheid en dat de mogelijkheid om invallers onbeperkt te laten invallen in geval van vervanging bij ziekte daar niet bij past. ${ }^{26}$ Hij acht de regeling in de CAO PO 2018-2019, waarbij gedurende een periode van maximaal drie jaar een onbeperkt aantal contracten kan worden gesloten, al een zeer ruime regeling waarna een docent zekerheid op vast werk zou moeten krijgen. Het amendement is verworpen. De regering benadrukt naar aanleiding van vragen van de PvdA-fractie dat de uitzondering alleen bedoeld is voor de situatie dat als gevolg van ziekte van een leerkracht een acuut probleem ontstaat en dat de uitzondering uitdrukkelijk niet geldt voor structurele vervanging die verder gaat dan het tijdelijk vervangen van een zieke leerkracht. Daarmee is de uitzondering op de ketenregeling volgens de regering gerechtvaardigd en in overeenstemming met Richtlijn 1999/70/EG en de rechtspraak van het Hof van Justitie van de Europese Unie. $^{27}$

Ook in het openbaar onderwijs heeft men te maken met de ketenregeling. Zo is in de CAO PO 2018-2019 voor het openbaar onderwijs de volgende ketenregeling opgenomen:

\footnotetext{
Kamerstukken I/ 2018/19, 35074, 3, par. 2.2.2

Kamerstukken I/ 2018/19, 35074, 4, p. 12-13

Kamerstukken I/ 2018/19, 35074, 24.

Kamerstukken I 2018/19, 35074, D, p. 21-23
}

'Vanaf de dag dat tussen dezelfde werkgever en werknemer aanstellingen voor bepaalde tijd elkaar met tussenpozen van niet meer dan 3 maanden hebben opgevolgd en een periode van 36 maanden, deze tussenpozen inbegrepen, hebben overschreden, geldt met ingang van die dag de laatste aanstelling als een aanstelling voor onbepaalde tijd.'

Vanaf 1 januari 2020 zal de ketenregeling van artikel 7:668a $\mathrm{BW}$ in het openbaar onderwijs van toepassing zijn, inclusief de wijzigingen die de WAB met zich brengt. Er is veel discussie geweest over het overgangsrecht, in het bijzonder de vraag of aanstellingen van voor 1 januari 2020 meetellen in de keten. ${ }^{28}$ Uit een nota van wijziging bij de aanpassingswet Wnra volgt dat deze vraag bevestigend moet worden beantwoord. ${ }^{29}$ In een nieuw voorgesteld artikel 14 lid 3 AW 2017 wordt geregeld dat voorgaande aanstellingen meetellen als waren zij arbeidsovereenkomsten. Daarbij geldt op grond van artikel 14 lid 1 AW 2017 dat de aanstelling van rechtswege wordt omgezet in een arbeidsovereenkomst.

\section{Rechtsbescherming}

De vaststelling of iemand werkzaam is in het bijzonder onderwijs of het openbaar onderwijs is ook van belang voor de rechtsbescherming bij ontslag. ${ }^{30}$ Voor werknemers in het bijzonder onderwijs geldt, afhankelijk van de ontslaggrond, een preventieve ontslagtoets. Afhankelijk van de ontslaggrond wordt deze toets uitgevoerd door het UWV (bedrijfseconomisch ontslag (kan ook door een cao-ontslagcommissie worden getoetst als deze is ingesteld) of langdurige arbeidsongeschiktheid) of door de kantonrechter (overige ontslaggronden). Voor wat betreft het procesrecht is artikel 7:686a BW relevant. In dit wetsartikel is onder meer geregeld dat gedingen over het einde van de arbeidsovereenkomst worden ingeleid met een verzoekschrift (lid 2) en zijn de vervaltermijnen opgenomen (lid 4).

De rechtsbescherming van de ambtenaar in het openbaar onderwijs wordt beheerst door het bestuursrecht. Op grond van de Algemene wet bestuursrecht (hierna: Awb) kan een ambtenaar tegen het besluit tot ontslag binnen zes weken een bezwaarschrift of beroepschrift indienen (art. 6:7 Awb). Na het doorlopen van de bezwaar- en beroepsprocedure kan hoger beroep worden ingesteld bij de Centrale Raad van Beroep. In de bezwaarprocedure wordt een besluit in het geheel her-

28. Zie ook: L.C.J. Sprengers e.a. Op weg naar één arbeidsrecht voor de gehele onderwijssector. Gevolgen van de Wet normalisering rechtspositie ambtenaren (Wnra) voor ambtenaren in het openbaar primair en voortgezet onderwijs en aandachtspunten voor cao-partijen, Utrecht: Expertisecentrum Onderwijsgeschillen 2019, p. 15-19.

29. Kamerstukken // 2018/19, 35073, 6.

30. Zie hierover en de gevolgen van de Wnra in dit verband: M.Y.H.G. Erkens en M.A. Schneider, 'Normalisering en rechtsbescherming: een proces "in reverse"', in: B. Barentsen, N. Hummel en S.F.H. Jellinghaus (red.), Van ambtenaar naar ambtenaar. De Wet normalisering rechtspositie ambtenaren, Weert: Celsus uitgeverij 2018, p. 103-122. 
overwogen, terwijl in (hoger) beroep een marginale toetsing plaatsvindt. ${ }^{31}$ In beroep of hoger beroep zijn verschillende uitkomsten mogelijk: het beroep kan gegrond, ongegrond of niet-ontvankelijk worden verklaard of de bestuursrechter kan zich onbevoegd verklaren (art. 8:70 $\mathrm{Awb})$. $\mathrm{Na}$ invoering van de Wnra zullen de verschillen in rechtsbescherming voor personeel in het bijzonder en openbaar onderwijs er in ieder geval niet meer zijn.

De commissie van beroep die er nu al voor personeel in het bijzonder onderwijs is (hoewel deze commissie niet oordeelt over ontslag), kan dan wel ook van belang worden voor het personeel in het openbaar onderwijs. Voor bepaalde besluiten van de werkgever, zoals schorsing, overplaatsing of het onthouden van promotie, staat dan een laagdrempelige beroepsprocedure open. ${ }^{32}$

\section{Actualiteiten rechtspraak Hoge Raad ontslag onderwijswerknemer}

Werknemers in het bijzonder onderwijs zijn het afgelopen jaar aanleiding geweest voor twee uitspraken van de Hoge Raad over de transitievergoeding. In de eerste zaak, werkneemster/Stichting Kolom, gaat het om het volgende. ${ }^{33}$ Werkneemster is in dienst als leraar $\mathrm{LC}^{34}$ in het voortgezet onderwijs, waarbij de omvang van haar dienstbetrekking 0,9894 gedeelte van een volledige betrekking bedraagt. Op haar arbeidsovereenkomst is de CAO VO van toepassing. Sinds november 2013 is zij arbeidsongeschikt en haar wordt in 2015 een loongerelateerde WGA-uitkering toegekend. Vervolgens wordt haar per 29 februari 2016 een akte van ontslag verleend en ontvangt zij ook direct weer een akte van benoeming, die door werkneemster is ondertekend, met ingang van 1 maart 2016 voor $0,55 \%$ van de volledige betrekking. De kern van het geschil gaat over de vraag of werkneemster recht heeft op een volledige of gedeeltelijke transitievergoeding. Het hof had, kort samengevat, geoordeeld dat werkneemster geen recht had op een transitievergoeding, omdat de omzetting van het dienstverband naar een dienstverband met een lagere deeltijdfactor geen (gedeeltelijk) einde behelst aan de reeds bestaande arbeidsovereenkomst. De Hoge Raad oordeelt in cassatie dat in dit geval de voortzetting van de arbeidsovereenkomst erop neerkomt dat de bestaande arbeidsovereenkomst in feite gedeeltelijk is beëindigd en daarom naar evenredigheid van de omvang van die beëindiging een

31. S.F.H. Jellinghaus en E.G.M. Huisman, 'De ambtenaar' in: Arbeidsrechtelijke Themata - Bijzondere arbeidsverhoudingen, Den Haag: Boom juridisch 2017, p. 67-69.

32. L.C.J. Sprengers e.a. Op weg naar één arbeidsrecht voor de gehele onderwijssector. Gevolgen van de Wet normalisering rechtspositie ambtenaren (Wnra) voor ambtenaren in het openbaar primair en voortgezet onderwijs en aandachtspunten voor cao-partijen, Utrecht: Expertisecentrum Onderwijsgeschillen 2019, p. 43-46.

33. HR 14 september 2018, ECLI:NL:HR:2018:1617, JAR 2018/257 m.nt. J. Dop, AR-Updates 2018-1037 m.nt. J.P.M. van Zijl (Stichting Kolom).

34. LC staat voor het functieniveau. transitievergoeding verschuldigd is. Hoewel de wet geen gedeeltelijke transitievergoeding kent (de wet voorziet ook niet in de mogelijkheid een arbeidsovereenkomst gedeeltelijk te beëindigen), moet de mogelijkheid van gedeeltelijk ontslag met daaraan gekoppeld de aanspraak op een gedeeltelijke transitievergoeding wel worden aanvaard voor het bijzondere geval dat, door omstandigheden gedwongen, wordt overgegaan tot een substantiële en structurele vermindering van de arbeidstijd van de werknemer. Hierbij valt te denken aan het noodzakelijkerwijs gedeeltelijk vervallen van arbeidsplaatsen wegens bedrijfseconomische omstandigheden en aan blijvende gedeeltelijke arbeidsongeschiktheid van de werknemer. Indien een werknemer geen aanspraak zou maken op een gedeeltelijke transitievergoeding zou de werknemer door een substantiële en structurele vermindering van de arbeidstijd een deel van de transitievergoeding mislopen waarop hij bij een algehele beëindiging van de arbeidsovereenkomst op dat moment aanspraak zou hebben. De werknemer zou bij een na die vermindering plaatsvindende, algehele beëindiging van de arbeidsovereenkomst immers een op aanmerkelijk lagere grondslag berekende transitievergoeding ontvangen dan zonder die vermindering het geval zou zijn geweest, aldus de Hoge Raad. Tot slot geeft de Hoge Raad nog aanwijzingen wanneer sprake is van een gedeeltelijke beëindiging en wanneer sprake is van een substantiële en structurele vermindering van de arbeidstijd: bij een substantiële vermindering van de arbeidstijd gaat het om een vermindering van de arbeidstijd met ten minste twintig procent; bij een structurele vermindering van de arbeidstijd om een vermindering die naar redelijke verwachting blijvend zal zijn. De gedeeltelijke transitievergoeding dient berekend te worden naar evenredigheid van de vermindering van de arbeidstijd en uitgaande van het loon waarop voorheen aanspraak bestond, aldus de Hoge Raad. Concluderend heeft de praktijk in het onderwijs dat bij langdurige arbeidsongeschiktheid de arbeidsomvang (al dan niet in overleg met de werknemer) via een akte van ontslag en gelijktijdige akte van benoeming naar beneden wordt bijgesteld, de Hoge Raad ertoe gebracht een (niet uit de wet voortvloeiende) gedeeltelijke transitievergoeding in het leven te roepen. Dit roept de vraag op of de Hoge Raad hiermee niet een stap te ver gaat en of het niet aan de wetgever is voorbehouden dit wettelijk te regelen. ${ }^{35}$

In de zaak Stichting Katholieke Scholengroep voor Voortgezet Onderwijs X/werknemer gaat het om een docent die sinds 1978 in dienst is. ${ }^{36}$ In 2013 is de werknemer vanwege (langdurige) arbeidsongeschiktheid een WGA-uitkering toegekend, die in 2014 is omgezet in een IVA-uitkering. $\mathrm{Na}$ verkregen toestemming van het UWV heeft de Stichting de arbeidsovereenkomst per 23augustus 2016 wegens langdurige arbeidsongeschiktheid opgezegd. Op 30 april 2018 heeft de docent

35. D.J. Buijs, 'Transitievergoeding bij deeltijdontslag: een jurisprudentiële regel', TRA 2018/110

36. HR 5 oktober 2018, ECLI:NL:HR:2018:1845, NJ 2018/401, JAR 2018/275 m.nt. H.H.M.A. Foesenek. 
de AOW-gerechtigde leeftijd bereikt. De vraag die in dit geschil centraal staat is of toekenning van een volledige transitievergoeding ( $€ 73.541,42$ ) naar maatstaven van redelijkheid en billijkheid in de gegeven omstandigheden onaanvaardbaar is. De kantonrechter vond van wel en kende een transitievergoeding van $€ 25.000$ toe. Het hof kwam tot een ander oordeel. Naar het oordeel van het hof is van onaanvaardbare disproportionaliteit tussen het inkomensverlies van de docent en de verlangde transitievergoeding geen sprake. De transitievergoeding is een forfaitaire vergoeding die ook verschuldigd is indien niet of nauwelijks sprake is van schade of inkomensverlies. Er bestaat geen grond, ook niet als alle omstandigheden van het geval in samenhang worden beschouwd, om toekenning van een volledige transitievergoeding onaanvaardbaar te achten en op die grond te matigen, aldus het hof. De Hoge Raad oordeelt dat het oordeel van het hof geen blijk geeft van een onjuiste rechtsopvatting of andere motivering behoeft en verwerpt het cassatieberoep.

De rechtspraak met betrekking tot de onderwijswerknemer in het bijzonder onderwijs zal vanaf 1 januari 2020 ook van belang worden voor (nu nog) de ambtenaren in het openbaar onderwijs. Op basis van een onderzoek naar ontslaggronden en vergoedingen in het civiele recht vergeleken met het ambtenarenrecht concludeerde Houweling in 2017 (voordat het wetsvoorstel WAB werd ingediend) dat ontslag in het civiele recht minder snel gerealiseerd zal kunnen worden op de restgrond. Hij opperde dat het civiele recht met de restgrond (de hgrond; art. 7:669 lid 3 onder h BW) meer naar het ambtenarenrecht toe zou kunnen groeien als de restgrond echt als open restgrond wordt gehanteerd. $\mathrm{Na}$ inwerkingtreding van de WAB, waarbij een cumulatiegrond wordt geïntroduceerd op basis waarvan niet voldragen ontslaggronden kunnen worden gecombineerd en een werknemer aanspraak kan maken op 50\% extra transitievergoeding, zal ontslag in het civiele recht naar mijn idee iets meer opschuiven naar de restgrond in het ambtenarenrecht en makkelijker kunnen worden gerealiseerd. Verder concludeert Houweling dat de kans dat naast de minimumaanspraken een additionele billijke vergoeding moet worden betaald in het civiele recht en het ambtenarenrecht gelijk is, maar dat de vergoeding in het civiele recht doorgaans hoger is. ${ }^{37}$ De toekomst zal moeten uitwijzen in hoeverre ontslag onder het civiele recht anders zal worden dan onder het huidige ambtenarenrecht, waarbij de $\mathrm{WAB}$ van belangrijke invloed zal zijn.

\section{Conclusie}

In deze bijdrage is stilgestaan bij de ontslagbescherming van de onderwijswerknemer. Het duale onderwijsbestel, bestaande uit bijzonder en openbaar onderwijs, maakt dat er voor wat betreft de rechtspositie van personeel belangrijke verschillen zijn en altijd eerst moet worden beoordeeld welk wettelijk kader van toepassing is. Welk wettelijk kader voor het personeel ook van toepassing is, duidelijk is dat het onderwijs dubbel te maken krijgt met veranderingen. Voor werknemers in het bijzonder onderwijs is het arbeidsrecht de afgelopen jaren sterk aan verandering onderhevig geweest en dat is het nog steeds. De jurisprudentie van de Hoge Raad over Wwzvraagstukken is aardig op stoom en de Hoge Raad schroomt niet hier en daar aan rechtsvorming te doen, ook bij gebrek aan een wettelijke regeling. Denk aan de uitspraak over de gedeeltelijke transitievergoeding in geval van aanpassing van de omvang van de dienstbetrekking van een langdurige zieke leerkracht. Daarbij komt dat de WAB voor belangrijke veranderingen gaat zorgen. Voor personeel in het openbaar onderwijs brengt de Wnra belangrijke wijzigingen met zich. In plaats van het ambtenarenrecht zullen zij ineens te maken krijgen met het civiele arbeidsrecht, waaronder de WAB. Eén ding staat voor de onderwijssector na inwerkingtreding van de Wnra wel vast en dat maakt het toch wat overzichtelijker. Er zal nog maar één wettelijk kader van toepassing zijn: het civiele arbeidsrecht.

37. A.R. Houweling, 'Verambtelijking van het private ontslagrecht' in: B. Barentsen, N. Hummel en S.F.H. Jellinghaus (red.), Van ambtenaar naar ambtenaar. De Wet normalisering rechtspositie ambtenaren, Weert: Celsus uitgeverij 2018, p. 55. 